\title{
Assessing edge-of-field nutrient runoff from agricultural lands in the United States: How clean is clean enough?
}

\author{
R.D. Harmel, R.A. Pampell, A.B. Leytem, D.R. Smith, and R.L. Haney
}

\begin{abstract}
Excess nutrient loading from numerous sources (e.g., agricultural and urban runoff, treatment plant discharge, and streambank erosion) continues to adversely impact water resources, and determination of the cause(s) of accelerated nutrient enrichment has become a contentious and litigious issue in several US regions. This paper addresses one fundamental question: What are acceptable levels of nutrients in runoff from agricultural fields? It focuses on the field scale where farmers and ranchers make management decisions. Not answering this question limits the effectiveness of on-farm management and policy alternatives to address agriculture's contribution. To answer the question, some might suggest "direct comparison" with reference site data, existing criteria/standards, or measured data compilations Alternatively, "indirect assessments" using soil test phosphorus $(\mathrm{P})$ levels, $\mathrm{P}$ indices, field-scale models, or certainty programs might be suggested. Thus, to provide a scientific basis for policy debate and management decisions related to nutrient runoff from agricultural fields, we evaluated "direct comparisons" with measured data from case studies and evaluated "indirect assessment" alternatives. While acknowledging that scientific challenges and practical realities exist for each alternative, we concluded that certainty programs offer the most promise for ensuring acceptable nutrient runoff, and that field-scale models linked with watershed decision support tools are the most promising for assessing impacts on downstream water quality. Recognizing the reality that some nutrient loss is unavoidable from natural and anthropogenic sources, agriculture, industry, and municipalities are each encouraged to commit to implementing enhanced management where needed to minimize their sector's contribution to excess nutrients in our nation's waters.
\end{abstract}

Key words: Clean Water Act—nonpoint source pollution—nutrient criteria

\begin{abstract}
Well-managed agricultural soil and water resources benefit producers through reduced losses of valuable soil and nutrients, benefit the general public through reduced water treatment costs and increased reservoir storage, and benefit ecosystems through improved habitat and streamflow maintenance. In terms of nutrient runoff, this means managing fertilizer and organic amendments and/ or adopting conservation practices so that excessive nutrient runoff does not occur. In spite of the common belief in shared benefits along with concerted mitigation efforts, excess nutrients from many anthropogenic and natural sources (e.g., agricultural fertilizer and manure application, urban fertilization, wastewater treatment plants
\end{abstract}

enrichment and determination of the sources of excess nutrients has become a contentious issue. Litigation has occurred in the Florida Everglades (Chimney and Goforth 2001), the scenic interstate Illinois River in Oklahoma and Arkansas (Scott et al. 2011), a river and downstream drinking water supply in Texas (McFarland and Hauck 1999), and more recently the City of Des Moines, Iowa, Water Works (Henderson 2015). Concurrently, high profile instances of $\mathrm{N}$ and $\mathrm{P}$ enrichment in the Gulf of Mexico, Chesapeake Bay, and Lake Erie have increased public awareness.

The present work evaluates alternatives for assessing nutrient loss in runoff from agricultural fields with the ultimate goal of developing management decisions and resource policies that support economic and water resource sustainability. The fact that we cannot tell producers, policy makers, or management agencies "how clean is clean enough" in terms of acceptable levels of nutrients in runoff from agricultural lands hinders these efforts. Specifically, the objectives are to (1) evaluate potential alternatives, including "direct comparisons" and "indirect assessments" from a scientific and practical standpoint, and (2) articulate the state of the science and the anticipated challenges of assessing whether edge-of-field nutrient runoff is acceptable or excessive. To set the context for this discussion, an overview of the history of agricultural nonpoint source (NPS) pollution control in the United States is presented. The scope of this discussion is constrained to the field scale (edge-of-field) and farm scale where agricultural producers make management decisions that affect crop yields, profitability, and sustainability, as well as runoff water quality. Other pollutant sources, such as runoff and effluent discharges from Confined Animal Feeding Operations (CAFOs) and municipal, construction, and industrial stormwater, are regions. The natural contribution of nutrients to water bodies is undeniable as unimpacted landscapes such as native grasslands contribute average annual loads of $2 \mathrm{~kg} \mathrm{ha}^{-1}$ total nitrogen $(\mathrm{N})$ and $0.5 \mathrm{~kg} \mathrm{ha}^{-1}$ total phosphorus (P; Measured Annual Nutrient loads from AGricultural Environments [MANAGE] database) (Harmel et al.2006, 2008). For lakes and rivers, agriculture and municipal point sources are generally the largest contributors, whereas urban runoff and municipal point sources are the leading contributors for estuary impairments (USEPA 2015b, 2015c). In several US regions, accelerated nutrient
R. Daren Harmel is the director of the USDA Agricultural Research Service (ARS) Center for Agricultural Resources Research, Fort Collins, Colorado. Rehanon A. Pampell is a research associate for Texas A\&M Agrilife Research, Temple, Texas. April B. Leytem is a soil scientist at the Northwest Irrigation and Soils Research Laboratory, Kimberley, Idaho. Doug R. Smith is a soil scientist at the USDA ARS Grassland, Soil and Water Research Laboratory, Temple, Texas. Rick L. Haney is a soil scientist at the USDA ARS Grassland, Soil and Water Research Laboratory, Temple, Texas. 
not discussed, as they generally fall within the regulatory framework of the National Pollutant Discharge Elimination System.

Agricultural Nonpoint Source Pollution Control in the United States. In 1972, Congress overhauled water quality regulation in the United States by amending the Federal Water Pollution Control Act of 1948 and creating the Clean Water Act. The 1972 Clean Water Act focused federal regulatory authority on water quality degrading pollution from point sources rather than on ambient water quality (Craig and Roberts 2015). Prior to 1987, Section 208 was the only portion of the Clean Water Act to address NPS pollution. According to Williams (2002), the 1972 version of Section 208 provided three incentives for states to develop area-wide plans (cost share through US Environmental Protection Agency [USEPA] grants for plan development, cost share through USDA for best management practices, and state jurisdiction to allocate cleanup responsibilities); however, the program had limited success, as only 176 plans were developed. Federal funding supporting state development of Section 208 plans ended in 1980, leading to abandonment of most of the plans during the 1980s (Zaring 1996).

In 1987, Congress amended the Clean Water Act to specifically identify control of NPS pollution and point source pollution as tandem goals. The 1987 Clean Water Act established a national framework to address NPS pollution, including Section 319(h), which required states to assess NPS pollution and implement nutrient management programs. According to Craig and Roberts (2015), Congress intended for states to identify "the best management practices and measures which will be undertaken to reduce pollutant loadings resulting from each category, subcategory, or particular nonpoint source." The 1987 amendments also instructed states to "use regulatory and nonregulatory programs to achieve implementation of the best management practices (BMPs)" (Craig and Roberts 2015). In 1996, USEPA established a National Nonpoint Source Program, which expanded their role from grant oversight and administration into technical assistance and cooperation, to strengthen NPS management (USEPA 1997). Most states now have USEPAapproved NPS management programs, and most address agricultural NPS pollution. However, these programs vary considerably in terms of (1) whether they employ mandatory (regulatory) or voluntary measures, (2) how stringently they address agricultural NPS pollution, and (3) overall effectiveness (Craig and Roberts 2015).

Historically, most states have used narrative nutrient criteria or nutrient screening levels based on modeling or statistical data to protect waters from excess nutrients (American Farmland Trust 2013; EvansWhite et al. 2013; USEPA 2014). Narrative criteria are typically expressed in a qualitative form; for example, the Florida Surface Water Quality Criteria states that "in no case shall nutrient concentrations of a body of water be altered so as to cause an imbalance in natural populations of flora and fauna" (Florida Administrative Code, 62-302.530). However, with the 1998 Clean Water Action Plan, states were expected to adopt numeric nutrient criteria, and nutrient criteria development has focused on headwater and mid- and large-order streams, lakes, and estuaries. As defined by Williams (2002), water quality criteria are the minimally adequate ambient water condition(s) deemed necessary to support designated use(s), and thus they represent the ambient benchmark at which pollution controls are aimed. The assumption is that nutrient levels below that value are acceptable. Since 1998, Minnesota, Wisconsin, Florida, New Jersey, California, Nevada, Arizona, New Mexico, Montana, Oklahoma, Vermont, and Hawaii have established $\mathrm{N}$ and/or $\mathrm{P}$ criteria for rivers/streams (USEPA 2015a). Dodds and Welch (2000) and Evans-White et al. (2013) discuss the interaction between nutrients and aquatic life in terms of developing in-steam nutrient criteria, and Poole et al. (2004) discuss regime-based standards that consider the inherent spatial and temporal variations in natural water quality parameters.

Voluntary versus Mandatory Approaches for Regulating Nonpoint Source Pollution. Clean Water Act NPS provisions, other federal programs, and most state programs address agricultural nutrient runoff through producer education and technical/financial assistance for managing fertilizer and manure application and adopting conservation practices. The diffuse and episodic nature of NPS pollution, as well as programmatic challenges and social, geographic, economic, and political factors, prevent direct national regulation from being a feasible policy option (see USDA ERS [1999] and Haskell [2007] for in-depth discussion). In fact, one could logically argue that national regulation of runoff from agricultural fields would alter the very intent and design of the Clean Water Act if it focused liability and control on individual nonpoint sources, especially in light of the sheer magnitude of farms in the United States ( 2.1 million; USDA NASS 2014). Discussion of the complex socioeconomic and legal issues associated with NPS regulation is outside the scope of this manuscript; however, related scientific factors are presented.

According to Craig and Roberts' (2015) review of a 2012 Environmental Defense Fund survey, 19 US states have some type of NPS pollution regulation. These diverse regulations vary considerably in terms of trigger conditions for mandatory requirements and range from requirements applicable to BMPs and nutrient management plans; discharge from irrigated lands; watershed permitting; soil erosion and sediment discharge ordinances; and pesticide licensing, labeling, and disposal. Laws addressing agricultural NPS pollution are typically subjective and rely on general prohibitions such as "may not spray chemical in a manner that is likely to pollute..." (Environmental Law Institute 1998); however, some states have enacted more prescriptive requirements. For example, mandatory requirements for agricultural NPS pollution are tied to water quality impairments in Florida. When a water body is impaired (and thus subject to a total maximum daily load [TMDL]), the state identifies required BMPs and other measures and verifies implementation, but also provides cost share funds for implementation. In Oregon (Oregon Administrative Rule 603-090000), state regulation requires agricultural water quality management area plans that "...comprehensively outline measures that will be taken to prevent and control water pollution from agricultural activities..." The state prefers voluntary measures; however, "[e]nforceable mechanisms [are] available to address water pollution problems where voluntary compliance is not achieved." In Wisconsin, a nutrient management plan that meets a series of technical requirements including soil testing and is prepared by an agronomist or state-trained farmer is required to limit excess nutrient loading of soils to reduce nutrient pollution of waterways.

In the United States, the voluntary approach relies on planning, incentives, education, demonstration, and technical and 
financial assistance related to efficient fertilizer use and resource protection — all of which are delivered by university extension, soil and water conservation district, and USDA Natural Resources Conservation Service (NRCS) personnel. In addition, industry is leading numerous efforts to educate producers about improved nutrient management practices (e.g., 4R Nutrient Stewardship program developed by USDA NRCS). The voluntary approach has been successful in reducing sediment runoff and $\mathrm{N}$ and $\mathrm{P}$ runoff and leaching losses. These successes are reported in the NRCS Conservation Effects Assessment Project (CEAP) National Assessments (USDA NRCS 2011) and related work (White et al. 2014), which quantify the environmental effects of implementing conservation practices on agricultural landscapes including existing programs as well as potential alternatives.

Some countries have attempted to regulate NPS pollution with varied success. In the mid-1970s, the Netherlands identified N and $\mathrm{P}$ loading from agriculture as the leading cause of surface water eutrophication (Haskell 2007). In 1987, the Netherlands attempted to regulate and set standards for agricultural nutrient application mandating that all farms maintain government-approved nutrient management plans. These efforts failed because mandates focused on livestock operations, virtually ignoring cropland, and because manure-related transactions often went unreported and were thus unenforceable (Haskell 2007). However, Denmark's nutrient management legislation that coupled regulation with incentives decreased national surpluses of $\mathrm{N}(-41 \%)$ and $\mathrm{P}(-62 \%)$ relative to crop requirements from 1980 to 2006. Corresponding decreasing total N concentrations were observed in selected agricultural streams, but total $\mathrm{P}$ concentrations did not decrease (Maguire et al. 2009; American Farmland Trust 2013).

\section{Materials and Methods}

Determining Acceptable Levels of Edge-OfField Nutrient Runoff. It is quite interesting that no state NPS program mentions how to determine whether edge-of-field nutrient runoff is excessive (based on a review of the Environmental Law Institute [1998] summary of enforceable provisions of laws from each state that apply to NPS discharges including agriculture). In fact, not a single mention was made of determination or assessment of acceptable nutrient loss at the field scale, although a National Academy of Sciences (2012) report does allude to requiring point and diffuse sources to meet numeric nutrient criteria at the end-of-pipe or edge-of-field in its estimation of nutrient control costs. High profile instances of $\mathrm{N}$ and $\mathrm{P}$ enrichment are likely to bring increased attention in the future to agricultural nutrient contributions.

Establishing acceptable levels of nutrients in runoff from agricultural fields might be thought of as similar to the tolerable " $\mathrm{T}$ " rate for soil, with measured or estimated $\mathrm{N}$ and $\mathrm{P}$ losses compared to those values. If these targets are presumed to set legal limits on agricultural runoff, they will be fiercely debated because of Clean Water Act design and socioeconomic and political considerations, but these implications are outside the current scope.

The strategies we analyzed were meant to encompass all of the possibilities that could be reasonably proposed for assessing edgeof-field nutrient runoff. One category of alternatives is "direct comparisons" (table 1 ), in which measured values are compared to a target or screening level, numeric criterion, or water quality standard to determine whether losses are acceptable or excessive. The direct comparison alternatives do require measurement of water quality, which, because of the difficulty and number of fields, would be cost-prohibitive except in local areas; however, it was important to assess all options. Alternatively, "indirect assessments" (table 2) could be proposed to assess impacts of management strategies and BMPs on nutrient runoff potential and indirectly determine acceptable levels. These alternatives involve using a simple test, index, field-scale model, or management program to indirectly assess potential nutrient runoff. Direct comparison and indirect assessment alternatives are discussed subsequently. Recommendations based on the pros and cons of each are discussed from a practical standpoint to stimulate thought and facilitate scientific rationale and decision making related to assessing nutrient runoff.

\section{Results and Discussion}

Reference Site (Direct Comparison). One alternative that could be proposed for determination of acceptable nutrient runoff levels at the edge-of-field is using runoff water quality data from a reference site in the same ecoregion (e.g., Level III; Omernik 1987) to establish ecoregion-specific targets. For example, some states apply a reference watershed approach that uses an "unimpaired" watershed to establish acceptable loading rates that are then applied to the impaired watershed to calculate the TMDLs (American Farmland Trust 2013). USEPA recommends designating ecoregions with minimal impacts caused by human activities as reference sites to create baselines for nutrients (USEPA 2001). According to USEPA (2001), reference sites are pristine or minimally impacted sites, which in the current focus would mean they have few if any anthropogenic nutrient inputs. However, as defined by Stoddard et al. (2006), a "reference condition" can refer to a variety of biological conditions including historical, least disturbed, minimally disturbed, and best attainable.

Reference Site Evaluation. To evaluate this potential alternative, data from the USDA Agricultural Research Service (ARS) Riesel Watersheds, Riesel, Texas, were utilized because this research site includes pastures with conditions ranging from "minimally disturbed reference" to "excessive nutrient application." Concentrations of nitrate-N $\left(\mathrm{NO}_{3}-\mathrm{N}\right)$, ammonium-N $\left(\mathrm{NH}_{4}-\mathrm{N}\right)$, and orthophosphate- $\mathrm{P} \quad\left(\mathrm{PO}_{4}-\mathrm{P}\right)$ were measured in runoff events from 2004 to 2008 for three pasture watersheds: "reference" (SW12); "well-managed grazed" (SW17), and "excessive nutrient application" (Y14). The reference watershed (figure 1) is 1.2 ha and lies within 9.5 ha of native remnant tallgrass prairie that has never been plowed and receives nutrients only from atmospheric deposition, rainfall, and wildlife. The 1.2 ha well-managed grazed watershed was rotationally grazed with a moderate stocking rate $\left(\sim 1.5\right.$ ha animal unit $\left.{ }^{-1}\right)$.The 2.3 ha watershed with excessive nutrient inputs received 13.4 $\mathrm{Mg} \mathrm{ha}^{-1}$ of poultry litter annually from 2001 to 2007 and was hayed regularly.

Figure 2 shows measured nutrient concentrations in runoff from the three pasture conditions. For $\mathrm{NO}_{3}-\mathrm{N}$ and $\mathrm{NH}_{4}-\mathrm{N}$ runoff, mean concentrations for the well-managed grazed pasture were not significantly greater than for the reference site, but means for the pasture with excessive nutrients were significantly greater. These results related to land management indicate a potential to use mean values from reference sites to develop acceptable $\mathrm{N}$ runoff levels; however, this alternative did not produce reasonable results for P runoff. Since all three pasture 
Table 1

Summary of pros and cons for direct comparison alternatives for assessing nutrient runoff.

\begin{tabular}{|c|c|c|}
\hline $\begin{array}{l}\text { Direct } \\
\text { comparison } \\
\text { alternatives }\end{array}$ & Pros & Cons \\
\hline Reference site & $\begin{array}{l}\text { Water quality data collected from field(s) in question; } \\
\text { reasonable to establish targets relative to reference } \\
\text { conditions in same ecoregion. }\end{array}$ & $\begin{array}{l}\text { Require measurement of water quality, which is difficult } \\
\text { and expensive; numerous complicating factors } \\
\text { (e.g., sample type, data compilation, concentrations vs. } \\
\text { loads, allowable exceedances); unrealistic for agricultural } \\
\text { fields to have same or lower nutrient levels as reference } \\
\text { site, so some relative comparison would be necessary; } \\
\text { limited data from reference sites; substantial variability in } \\
\text { nutrient runoff even from reference sites. }\end{array}$ \\
\hline $\begin{array}{l}\text { Existing criteria } \\
\text { or standards }\end{array}$ & $\begin{array}{l}\text { Water quality data collected from field(s) in question; } \\
\text { reasonable to establish targets relative to existing } \\
\text { standards or criteria; stream nutrient criteria or screening } \\
\text { levels exist for many states; drinking water standards exist } \\
\text { for nitrate-nitrogen and nitrite-nitrogen. }\end{array}$ & $\begin{array}{l}\text { Require measurement of water quality, which is difficult } \\
\text { and expensive; numerous complicating factors } \\
\text { (e.g., sample type, data compilation, concentrations vs. } \\
\text { loads, allowable exceedances); scale difference difficult to } \\
\text { address (e.g., stream with multiple sources and in-stream } \\
\text { fate and transport mechanisms including dilution vs. } \\
\text { edge-of-field); unrealistic for agricultural fields to have } \\
\text { same or lower nutrient levels as drinking water, so some } \\
\text { relative comparison would be necessary; episodic nature } \\
\text { of runoff versus static target. }\end{array}$ \\
\hline $\begin{array}{l}\text { Measured data } \\
\text { compilation }\end{array}$ & $\begin{array}{l}\text { Water quality data collected from field(s) in question; based } \\
\text { on measured data from "similar" field; readily defensible } \\
\text { (strengthened if exhaustive data search and quality } \\
\text { assurance effort undertaken). }\end{array}$ & $\begin{array}{l}\text { Require measurement of water quality, which is difficult } \\
\text { and expensive; surprisingly limited amount of published, } \\
\text { land use specific data; data unequally distributed between } \\
\text { land uses, regions, etc. }\end{array}$ \\
\hline
\end{tabular}

conditions produced significantly different mean $\mathrm{PO}_{4}-\mathrm{P}$ concentrations, even the well-managed grazed pasture would be judged as exceeding the target if based on the reference site mean. This indicates a limitation of using reference site means as the target because even the well-managed grazed pasture would be judged as unacceptable with this alternative. Thus, the 90th percentile of runoff concentrations from the reference pasture was compared with the means of the other pastures. Using this alternative, $\mathrm{NO}_{3}-\mathrm{N}$ and $\mathrm{PO}_{4}-\mathrm{P}$ concentrations from the well-managed pasture did not exceed the target, but concentrations from the pasture with excessive nutrient inputs exceeded the target (figure 2).

Recommendations. In this evaluation the mean $\mathrm{PO}_{4}-\mathrm{P}$ concentration from well-managed pasture exceeded that of the reference prairie (figure 2), which points to a potential flaw of direct comparisons with reference data to determine acceptable levels of nutrient runoff at the edge-of-field. A more appropriate alternative would be to establish acceptable nutrient concentrations relative to some percentile of reference water quality (e.g., 90th). In this example, evaluating the mean of measured concentrations against the 90th percentile for the reference site would effectively detect high $\mathrm{NO}_{3}-\mathrm{N}$ and $\mathrm{PO}_{4}-\mathrm{P}$ concentrations due to excessive litter application rate (shown as "violations" in figure 2). Alternatively, using well-managed sites with recommended BMPs to develop the target would be preferred (although the specific definition of "well-managed sites" could also vary substantially even within ecoregions).

If comparisons with reference sites are utilized, the recently launched National Network of Reference Watersheds (NWQMC 2012) might be a valuable resource. With reference stream data for major Level 2 ecoregions, appropriate edge-of-field nutrient concentration targets could be established relative to the reference values. Even with such a network, Smith et al. (2003) point out that pristine reference sites are essentially nonexistent and that nutrient yields at undeveloped reference sites vary by more than two orders of magnitude; therefore, finding reference sites within the same watershed and/or same ecoregion and evaluating exceedances in the face of inherent variability would be challenging.

Existing Standards or Criteria (Direct Comparison). Comparison of nutrient runoff concentrations with existing stream nutrient criteria or drinking water standards is another possible alternative. Twelve states have nutrient criteria for streams/ rivers (USEPA 2015a), thus a comparison of these criteria versus measured field-scale water quality data could provide valuable insight; however, some scaling factor would likely be necessary to account for nutrient attenuation between the edge-of-field and the downstream receiving water. Another complicating factor is that instream criteria differ considerably in terms of nutrient forms (e.g., total $\mathrm{N}, \mathrm{NO}_{3}-\mathrm{N}$, total inorganic $\mathrm{N}, \mathrm{PO}_{4}-\mathrm{P}$, and total $\mathrm{P}$ ), reporting periods/ data types (e.g., annual mean, 90th percentile, mean of monthly means, or not to exceed), and geographic areas (e.g., statewide, individual streams, regional, and scenic rivers). Alternatively, acceptable concentrations could be determined relative to USEPA (2009) drinking water standards (maximum contaminant levels: $\mathrm{NO}_{3}-\mathrm{N}=10 \mathrm{mg} \mathrm{L}^{-1}$, nitrite $\left[\mathrm{NO}_{2}\right]-\mathrm{N}=1 \mathrm{mg} \mathrm{L}^{-1}$; none exist for $\mathrm{P})$, although adjustment would be needed to relate expectations of water quality in runoff versus drinking water. 
Table 2

Summary of pros and cons for indirect assessment alternatives for assessing nutrient runoff.

\section{Indirect \\ assessment \\ alternatives}

Soil Test $P$
Pros

Simple, existing alternative; effective tool for ranking

relative risks; relatively easy to assess.
Cons

Water quality protection is presumed not definitively confirmed; numerous factors affect $P$ runoff (e.g., fertilizer rate, application timing, erosion, etc.)- therefore, may not be good indicator of nutrient loss; various extractants and soil conditions produce different soil test $\mathrm{P}$ values; soil test P levels can be "manipulated” (e.g., sampling location, additional irrigation); does not address $\mathrm{N}$ runoff.

\begin{tabular}{|c|c|c|}
\hline $\begin{array}{l}\text { P Index or } \\
\text { similar } \\
\text { "environmental } \\
\text { index" }\end{array}$ & $\begin{array}{l}\text { Existing, widely accepted alternative; effective tool for } \\
\text { ranking relative risks; can be tailored to account for } \\
\text { local/regional differences; relatively easy to assess loss } \\
\text { relative to P loss rating or estimate of concentrations or } \\
\text { loads; significant freedom to design methods (BMPs } \\
\text { and/or management strategies) to achieve target; can help } \\
\text { target effort and resources on fields with the greatest } \\
\text { likelihood of contributing excess nutrient runoff. }\end{array}$ & $\begin{array}{l}\text { Water quality protection is presumed not definitively } \\
\text { confirmed; directly conflicts with } \mathrm{P} \text { Index purpose if used } \\
\text { to evaluate compliance or as a regulatory tool; does not } \\
\text { address } \mathrm{N} \text { runoff. }\end{array}$ \\
\hline $\begin{array}{l}\text { Field-scale } \\
\text { model }\end{array}$ & $\begin{array}{l}\text { Existing technology; capable of estimating actual losses and } \\
\text { impacts of management; can account for local/regional } \\
\text { differences; easy to assess loss relative to predicted loss } \\
\text { from model; significant freedom to design methods } \\
\text { (BMPs and/or management strategies) to achieve target; } \\
\text { utilizes best available science (nutrient cycling routines); } \\
\text { can help target effort and resources on fields with the } \\
\text { greatest likelihood of contributing excess nutrient runoff; } \\
\text { can be used in conjunction with larger scale models to } \\
\text { assess impacts on downstream water quality. }\end{array}$ & $\begin{array}{l}\text { Water quality protection is presumed not definitively } \\
\text { confirmed; not vigorously validated in all regions. }\end{array}$ \\
\hline $\begin{array}{l}\text { Certainty } \\
\text { programs }\end{array}$ & $\begin{array}{l}\text { Proactive; can be tailored to account for local/regional } \\
\text { differences; relatively easy to assess; significant freedom } \\
\text { to design methods (BMPs and/or management strategies) } \\
\text { to achieve target; provides legal protection to producer; } \\
\text { utilizes best available science (science-based practice } \\
\text { selection and placement); includes renewal provision so } \\
\text { that advances in knowledge and improved practices can } \\
\text { be incorporated; supported by US Environmental Protection } \\
\text { Agency and Natural Resources Conservation Service. }\end{array}$ & $\begin{array}{l}\text { Water quality protection is presumed not definitively } \\
\text { confirmed; program monitoring required to assure } \\
\text { practice installation and maintenance. }\end{array}$ \\
\hline
\end{tabular}

Notes: $\mathrm{P}=$ phosphorus. $\mathrm{N}=$ nitrogen. $\mathrm{BMP}=$ best management practice.
Existing Standards or Criteria Evaluation. Measured data from various states were needed to conduct this evaluation; therefore, all measured concentration data were extracted from the MANAGE database (Harmel et al. 2006, 2008). MANAGE is the only known near-comprehensive compilation of measured load and concentration data from agricultural and forest lands. Studies in MANAGE must have been published in a peer-reviewed journal, report data from single land uses $(>0.009$ ha), and have at least one year of runoff data generated by natural precipitation.
Examination of measured data in MANAGE revealed that only three states with instream criteria (Florida, Minnesota, and Oklahoma) have more than a few siteyears of measured field-scale concentration data (figure 3). As shown in table 3, data from Florida and Minnesota were from only one study each. In those limited data sets, total P concentrations measured at the edge-of-field greatly exceeded the state's instream criteria. Oklahoma had 244 site-years of measured field-scale data. However, a majority of the Oklahoma data were taken in the arid and semiarid central and western portions of the state, whereas the total $\mathrm{P}$ criterion applies to the scenic rivers located in the humid east, making the comparison less relevant.

To expand this analysis, nutrient screening levels and measured data from Texas were included. In the absence of numerical nutrient criteria in the state of Texas water quality standards, narrative nutrient criteria for freshwater streams are evaluated by screening levels (TCEQ 2010), which are set as the 85th percentile values from the state monitoring database. A "concern" for 


\section{Figure 1}

Remnant native prairie reference site at the USDA Agricultural Research Service Riesel Watersheds.

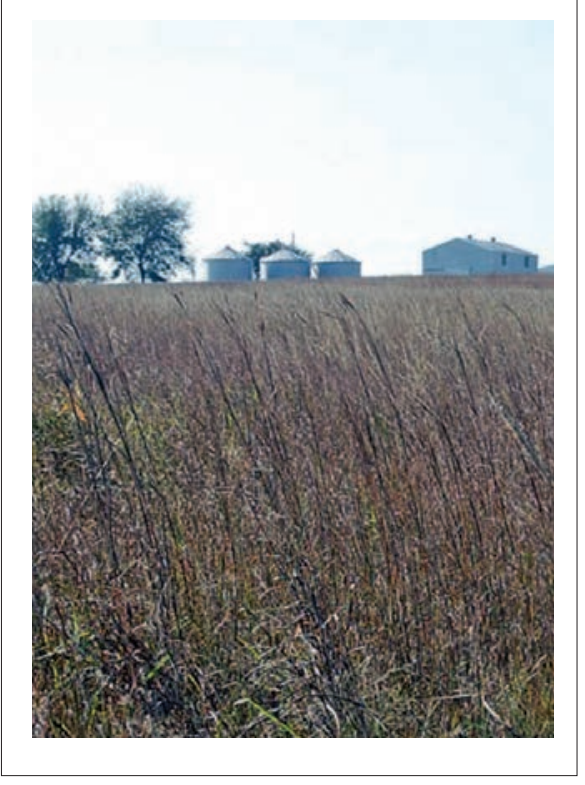

excessive nutrient levels is indicated if the screening level is exceeded in greater than $20 \%$ of samples. The screening levels for these nutrient parameters, which were statistically derived or were based on published levels of concern, establish targets that can be directly compared to monitoring data. When the screening levels were compared to all measured data in MANAGE from Texas, the 80th percentile in measured data were all very similar to the screening levels (table 3 ). This offers promise that the screening levels developed with a similar method to that used in Texas may be a reasonable starting point for establishing edge-of-field targets. However, data from three of four ungrazed native (reference) fields in Texas produced average dissolved $\mathrm{P}$ concentrations that exceeded the $0.37 \mathrm{mg} \mathrm{L}^{-1}$ screening level, which indicates that some modification might be required.

To further evaluate the alternative of using the Texas nutrient screening level to establish edge-of-field targets, screening levels were compared to measured runoff data from Riesel, Texas (Harmel et al. 2014). This comparison revealed potential problems with this alternative. Twelve years of event mean concentrations (EMCs) for $\mathrm{NO}_{3}-\mathrm{N}$, $\mathrm{NH}_{4}-\mathrm{N}$, and $\mathrm{PO}_{4}-\mathrm{P}$ from a remnant native tallgrass prairie (SW12) indicated "no concern" (table 4), which is the expected and appropriate result for reference site runoff. In contrast, eight years of data from hay pastures, one with excessive poultry litter application (Y14) and one with "recommended" litter rates (W10), indicated "no concern" for $\mathrm{NO}_{3}-\mathrm{N}$ and $\mathrm{NH}_{4}-\mathrm{N}$ but "concern" for $\mathrm{PO}_{4} \mathrm{P}$ based on the Texas screening levels. In this case, the screening levels were not able to differentiate between proper and improper management, specifically poultry litter application and crop $\mathrm{P}$ requirements on hay pasture. Even the reference prairie site produced $\mathrm{PO}_{4}-\mathrm{P}$ concentrations in excess of the $0.37 \mathrm{mg} \mathrm{L}^{-1}$ screening level in $11 \%$ of runoff events. Similarly, based on four years of data from four cultivated fields, all with conservation management practices (i.e., terraces and grassed waterways), screening levels were not able to differentiate proper and improper nutrient management. Regardless of whether they received recommended or excessive fertilizer rates, cultivated sites generally showed "concern" for $\mathrm{NO}_{3}-\mathrm{N}$ and $\mathrm{PO}_{4}-\mathrm{P}$. This conclusion of "concern" is likely not warranted because the management practices for Y13 were certainly more stringent than recommended practices, and the $13.4 \mathrm{Mg} \mathrm{ha}^{-1}$ litter rate for Y8 was no doubt excessive. These results related to litter as an organic $\mathrm{N}$ and $\mathrm{P}$ source are likely influenced by residual $\mathrm{N}$ and $\mathrm{P}$ from previous applications. Conversely, site Y6 with very high inorganic $\mathrm{N}$ rates showed no concern for $\mathrm{NO}_{3}-\mathrm{N}$, but showed concern for $\mathrm{PO}_{4}-\mathrm{P}$ even with relatively low $\mathrm{P}$ application and low soil test $\mathrm{P}$ levels.

When the $\mathrm{NO}_{3}-\mathrm{N}$ drinking water standard was compared to all measured concentration data in MANAGE, the 95th percentile in measured data corresponded to the $10 \mathrm{mg}$ $\mathrm{L}^{-1}$ standard (table 3 ). However, it should be kept in mind that most of the concentration data in MANAGE are averaged somehow. In other words, most are annual or seasonal means or medians, not individual measured concentrations, which would certainly be higher than $10 \mathrm{mg} \mathrm{L}^{-1}$ at times.

Recommendations. At the larger (stream/ river) scale, the integrated effects of numerous nutrient sources including agriculture can be assessed; however, the direct application of stream/river criteria at the edge-of-field scale is not appropriate. Establishing a link between edge-of-field nutrient losses and stream/river concentrations will at a minimum require an acknowledgement of the differences in scales and types and number of sources involved, as well as nutrient attenuation between fields and downstream receiving waters.

Based on the compilation of measured data for Texas in MANAGE, the Texas nutrient screening levels (TCEQ 2010) seemed to offer promise as a reasonable starting point for establishing acceptable nutrient concentrations at the edge-of-field. However, when data from an individual research site with multiple watersheds were examined, the nutrient screening levels were not able to properly differentiate acceptable runoff concentration for well-managed sites and unacceptable levels for improperly managed sites (table 4); therefore, adjustment would be necessary.

The $10 \mathrm{mg} \mathrm{L}^{-1} \mathrm{NO}_{3}-\mathrm{N}$ drinking water standard might also be a reasonable criterion if it was determined that the 95th percentile in measured runoff concentrations represented acceptable $\mathrm{NO}_{3}-\mathrm{N}$ concentrations. However, that standard would only be appropriate for annual/seasonal means or medians because individual measured concentrations would be higher than $10 \mathrm{mg} \mathrm{L}^{-1}$ at times regardless of management (as shown in MANAGE).

Measured Data Compilation (Direct Comparison). Comparison of nutrient levels in edge-of-field runoff to levels in compilations of such data could also be proposed as an alternative. Ideally, adequate data from a particular state/ecoregion and land use would be available from which to establish a level (likely represented by some percentile, e.g., 75th, 90th, or 95th) above which nutrient concentrations are deemed unacceptable.

Measured Data Compilation Evaluation. Since the MANAGE database (Harmel et al. 2006, 2008) is the only known nearcomprehensive compilation of measured load and concentration data from agricultural land uses, it was again used for this evaluation. This alternative was able to detect differences in runoff nutrient concentrations between crops and to detect regional differences, which is an attractive feature if this alternative were used to assess nutrient runoff relative to targets. For example, $\mathrm{NO}_{3}-\mathrm{N}$ losses from corn (Zea mays L.) were greater than for cotton (Gossypium hirsutum), wheat (Triticum aestivum L.), soybeans (Glycine max L.), and pasture (figure 4). Additionally, average $\mathrm{NO}_{3}-\mathrm{N}\left(12 \mathrm{mg} \mathrm{L}{ }^{-1}\right.$ versus $\left.3.4 \mathrm{mg} \mathrm{L}^{-1}\right)$ and dissolved $\mathrm{P}$ (0.51 $\mathrm{mg} \mathrm{L}^{-1}$ versus 0.35 $\mathrm{mg} \mathrm{L}^{-1}$ ) concentrations were higher in Texas than in the Corn Belt states of Iowa, Illinois, Minnesota, and Wisconsin. 


\section{Figure 2}

Measured nutrient concentrations from three pasture conditions: reference, well-managed grazed, and excessive nutrient application. Dots represent outliers, whiskers represent the 1oth and goth percentiles, box edges represent the $25^{\text {th }}$ and $75^{\text {th }}$ percentiles, solid lines represent the median, and dotted lines represent the mean. For each nutrient, mean concentrations with the same letter are not significantly different based on a 2-sample $t$-test $(\alpha=0.10)$. An example "violation" is indicated when the mean exceeds the goth percentile from the reference pasture.
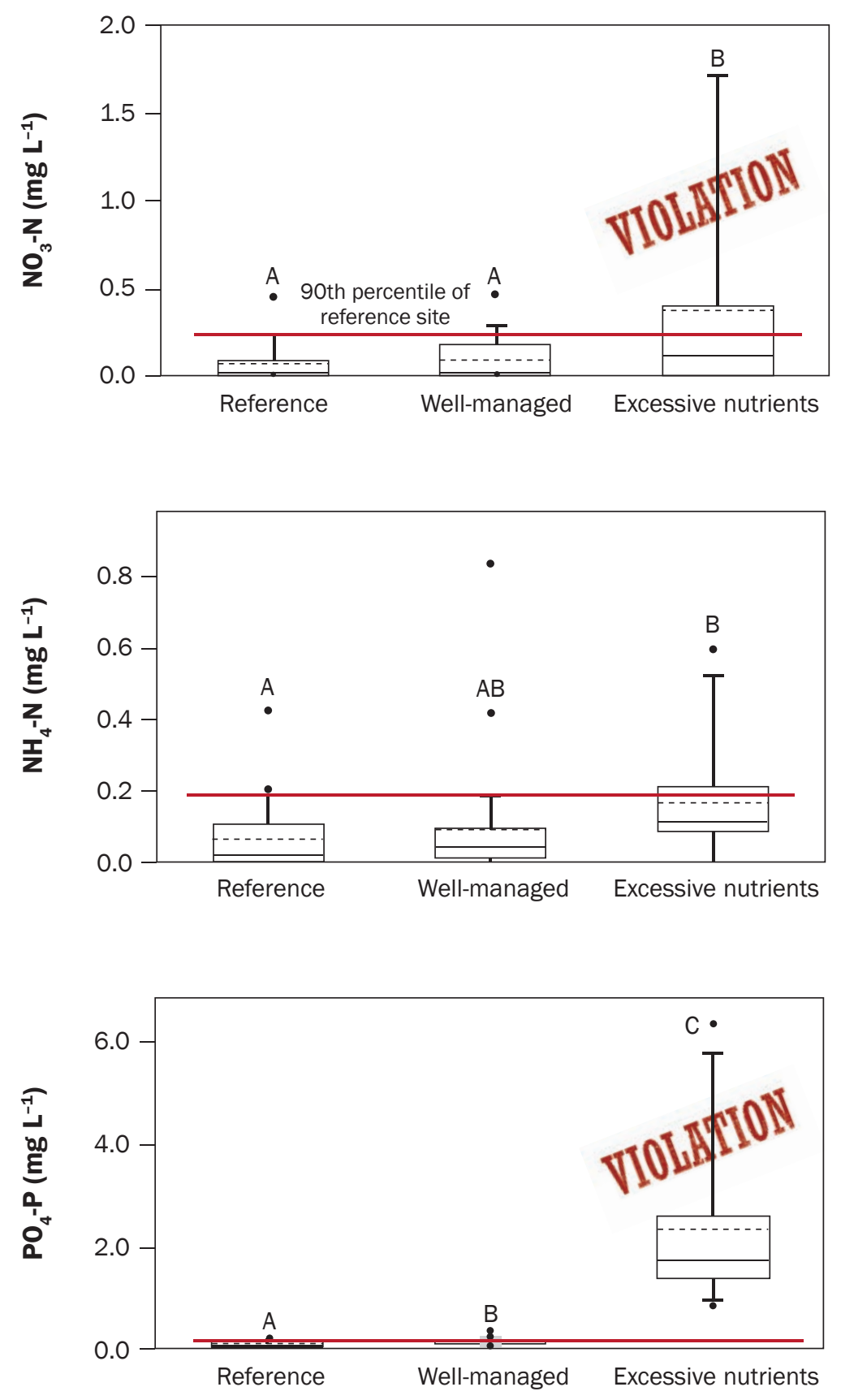

Several deficiencies also became apparent, however, upon further examination. The time frame of reported data varied substantially (e.g., annual, annual flow-weighted mean, annual geometric mean, annual mean, event, event mean, mean, quarterly mean, growing season mean, single event, study period, and study period mean), which weakened subsequent comparisons. Similarly, studies often measured different constituent types, which contributed to some likely unrealistic results (e.g., total $\mathrm{N}$ concentrations were lower than dissolved and/or particulate $\mathrm{N}$ concentrations for corn, cotton, and pasture).

Limited data for certain crops, nutrients, and geographic regions added to the difficulty of applying this alternative. Average nutrient concentrations for at least one constituent type $\left(\mathrm{NO}_{3}-\mathrm{N}, \mathrm{NH}_{4}-\mathrm{N}\right.$, particulate $\mathrm{N}$, total $\mathrm{N}$, dissolved $\mathrm{P}$, particulate $\mathrm{P}$, or total $\mathrm{P}$ ) were reported for only 1,067 siteyears (54\% of total) and only 207 fields/ treatment units (63\% of total). For example, all of the particulate $\mathrm{N}$ data for corn were from only one Iowa study, and that study produced high concentrations. Similarly, all of the total $\mathrm{N}$ data for corn were from only one Alabama study, which used a winter rye (Secale cereale) cover crop that contributed to low total $\mathrm{N}$ concentrations (figure 4). The impact of limited data was also evident in particulate $\mathrm{P}$ concentrations for pastures. That land use produced one value $>90 \mathrm{mg}$ $\mathrm{L}^{-1}$, but all others were $<3 \mathrm{mg} \mathrm{L}^{-1}$.

A similar analysis was conducted with the load data to overcome deficiencies due to limited concentration data and differing time frames and constituent types. Each study in MANAGE reported annual loads in kilograms per hectare (figure 5). The additional values minimized the influence of extreme values; however, total $\mathrm{N}$ and total $\mathrm{P}$ percentiles were still not always realistic, as they were lower than dissolved and/or particulate forms because not all studies measured all constituent types. This analysis was also able to better detect expected differences in crops. For example, dissolved, particulate, and total $\mathrm{N}$ loads as well as particulate and total $\mathrm{P}$ loads from corn were greater than for the other land uses with lower typical $\mathrm{N}$ and $\mathrm{P}$ application rates. In terms of detecting expected regional differences, $\mathrm{N}$ and $\mathrm{P}$ loads were again compared for Texas and the midwestern states of Iowa, Illinois, Indiana, Minnesota, Missouri, and Wisconsin. The Midwest states produced the following 


\section{Figure 3}

States with instream nutrient criteria (gray). Numbers represent site-years of nutrient concentration data in the Measured Annual Nutrient loads from AGricultural Environments database.

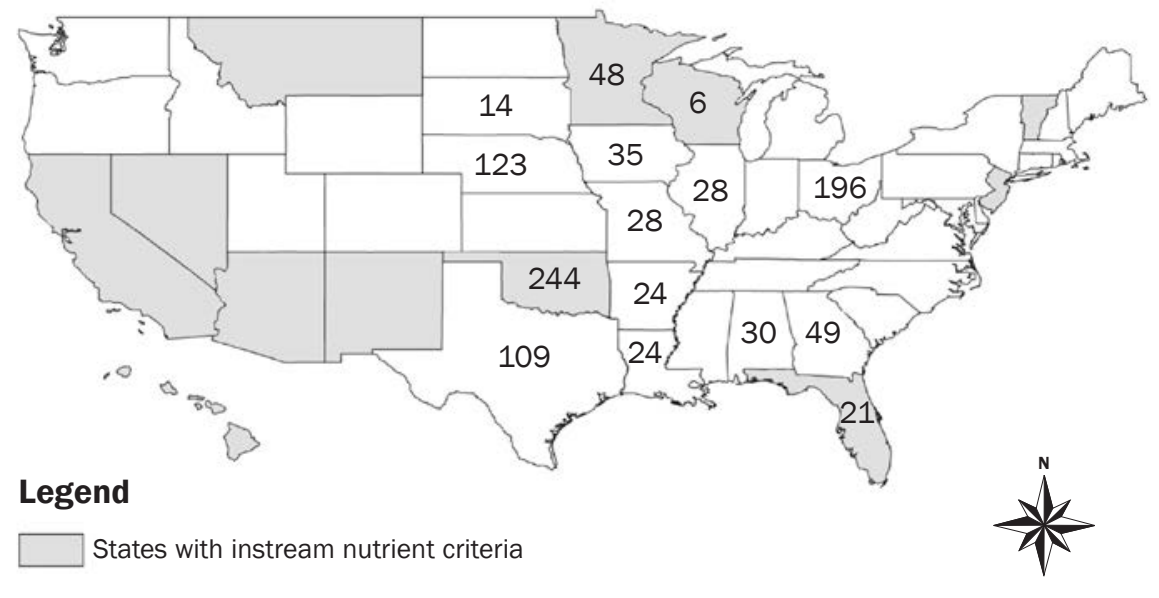

average annual loads: $3.5 \mathrm{~kg}$ dissolved $\mathrm{N} \mathrm{ha}^{-1}$, $25.5 \mathrm{~kg}$ total $\mathrm{N} \mathrm{ha}^{-1}, 0.2 \mathrm{~kg}$ dissolved $\mathrm{P} \mathrm{ha}^{-1}$, and $3.3 \mathrm{~kg}$ total $\mathrm{P} \mathrm{ha}^{-1}$. Dissolved $\mathrm{N}(19.4 \mathrm{~kg}$ $\left.\mathrm{ha}^{-1}\right)$ and $\mathrm{P}\left(1 \mathrm{~kg} \mathrm{ha}^{-1}\right)$ loads were higher in Texas, but total $\mathrm{N}$ and $\mathrm{P}$ loads were very similar. Whether or not these results are artifacts of the studies included is unknown. Higher rainfall, soil $\mathrm{N}$ and $\mathrm{P}$ levels, and fertilizer inputs in the Midwest would contribute to higher runoff losses, but tile drainage would lessen runoff and increase leaching losses.

Recommendations. In regions with adequate measured data, utilizing data compilations to establish edge-of-field concentration or load targets appears to be the most defensible direct comparison alternative (as with all direct comparisons, however, the immense cost of collecting and analyzing runoff samples would need serious discussion). If this alternative were pursued, concerted effort to include all relevant, ecoregion specific data from all credible sources (e.g., journals, grant reports, and extension publications) would strengthen it substantially. The percentile deemed acceptable would also require considerable discussion, but 75 th to 95th percentiles would likely be reasonable to differentiate between acceptable and excessive nutrient runoff loss. Similarly, care would need to be used to assure data compilations represent a realistic range of actual concentrations. In other words, including too much "high nutrient loss data" would result in a relatively high target and not protect water quality, but the opposite could also occur resulting in overly stringent targets.

Soil Test Phosphorus (Indirect Assessment). The most widely used indirect method of assessing $\mathrm{P}$ runoff potential is to test for soil test P levels, and this alternative could be proposed to indirectly evaluate nutrient runoff. Many states use this method to determine $\mathrm{P}$ application thresholds with the assumption that soil $\mathrm{P}$ concentrations below a critical level will produce acceptable levels of P runoff (Sharpley et al. 2001; Turner et al. 2004; Regan et al. 2014). Dissolved P concentrations in runoff have been shown to be correlated to soil test P levels; however, these same studies also noted that additional factors (e.g., runoff and erosion variability) need to be considered for accurate prediction of P runoff losses (Sharpley et al. 1996; DeLaune et al. 2004; Harmel et al. 2009).

Enhanced soil testing such as using the degree of $\mathrm{P}$ saturation helps improve the threshold predictions over a range of soil types (Schroeder et al. 2004; Tarkalson and Mikkelsen 2004; Zheng et al. 2014), but will not necessarily account for the other critical factors associated with overland P transport. Another complication is the ability to obtain representative soil samples for evaluating the susceptibility of $\mathrm{P}$ losses from a field, as soil test $\mathrm{P}$ can have great spatial variability and the zone of soil-water interaction will depend on field characteristics and management (Ahuja et al. 1981; Mzuku et al. 2005; Grandt et al. 2008).

Recommendations. Although utilizing a soil test is a simple method for identifying the potential for nutrient losses from agricultural fields, it also has many limitations. A soil sample only provides one piece of necessary information related to off-site transport of nutrients. Other factors such as fertilizer and manure applications, nutrient application methods and timing, and transport factors (erosion, runoff, etc.) must be considered to fully evaluate potential for off-site movement.

Phosphorus Index (Indirect Assessment). According to Lemunyon and Gilbert (1993), the use of soil test $\mathrm{P}$ thresholds was viewed as restrictive and potentially ineffective at reducing NPS losses of $\mathrm{P}$; therefore, almost all states use the $\mathrm{P}$ index approach (Osmond et al. 2006). The various $P$ indices were developed based on source and transport factor research (Sharpley et al. 2003) and in many cases were refined by professional judgment and/or small plot rainfall simulation studies (DeLaune et al. 2004).

Most P indices were developed to evaluate the relative risk of $\mathrm{P}$ loss from fields based on source and transport factors, and as such this alternative could be proposed to indirectly evaluate nutrient runoff. The resulting qualitative risk rankings (e.g., low, medium, and high) were designed to focus effort and resources on areas with the greatest likelihood of contributing $\mathrm{P}$ to surface (and in some instances subsurface) waters. As these indices include management practices for reducing $\mathrm{P}$ losses, they can be valuable tools to help producers identify practices to reduce the potential for off-site $\mathrm{P}$ transport.

A few $\mathrm{P}$ indices were designed to estimate actual P loss from fields, but even so they often present a normalized value or risk ranking instead. For example, the Iowa $\mathrm{P}$ Index approximates the amount of $\mathrm{P}$ potentially delivered to surface water and uses approximate units of pounds of $\mathrm{P}$ per acre per year for assumed long-term average conditions with the caveat that the index is not intended to be used for prediction of actual $\mathrm{P}$ delivered to surface water from fields (Mallarino et al. 2002). More recently, Iowa used their P index to model average $\mathrm{P}$ reductions needed and select appropriate management practices for the Iowa Nutrient Reduction Strategy. The North Carolina Phosphorus Loss Assessment Tool predicts annual $\mathrm{P}$ loss and classifies it into the following rating categories: Low (0 to $1.12 \mathrm{~kg}$ $\mathrm{ha}^{-1}$ ), Medium (1.13 to $2.24 \mathrm{~kg} \mathrm{ha}^{-1}$ ), High (2.25 to $\left.4.48 \mathrm{~kg} \mathrm{ha}^{-1}\right)$, and Very High $(>4.48$ $\mathrm{kg} \mathrm{ha}{ }^{-1}$; Johnson et al. 2005). The Arkansas $\mathrm{P}$ Index also predicts losses, and fields are assigned a $\mathrm{P}$ index risk rating of Low $(<0.67$ $\left.\mathrm{kg} \mathrm{P} \mathrm{ha}{ }^{-1}\right)$, Medium (0.67 to $\left.1.34 \mathrm{~kg} \mathrm{P} \mathrm{ha}^{-1}\right)$, High (1.34 to $2 \mathrm{~kg} \mathrm{P} \mathrm{ha}^{-1}$ ), orVery High (>2 
Table 3

Comparison of instream criteria and screening levels to measured field-scale data.

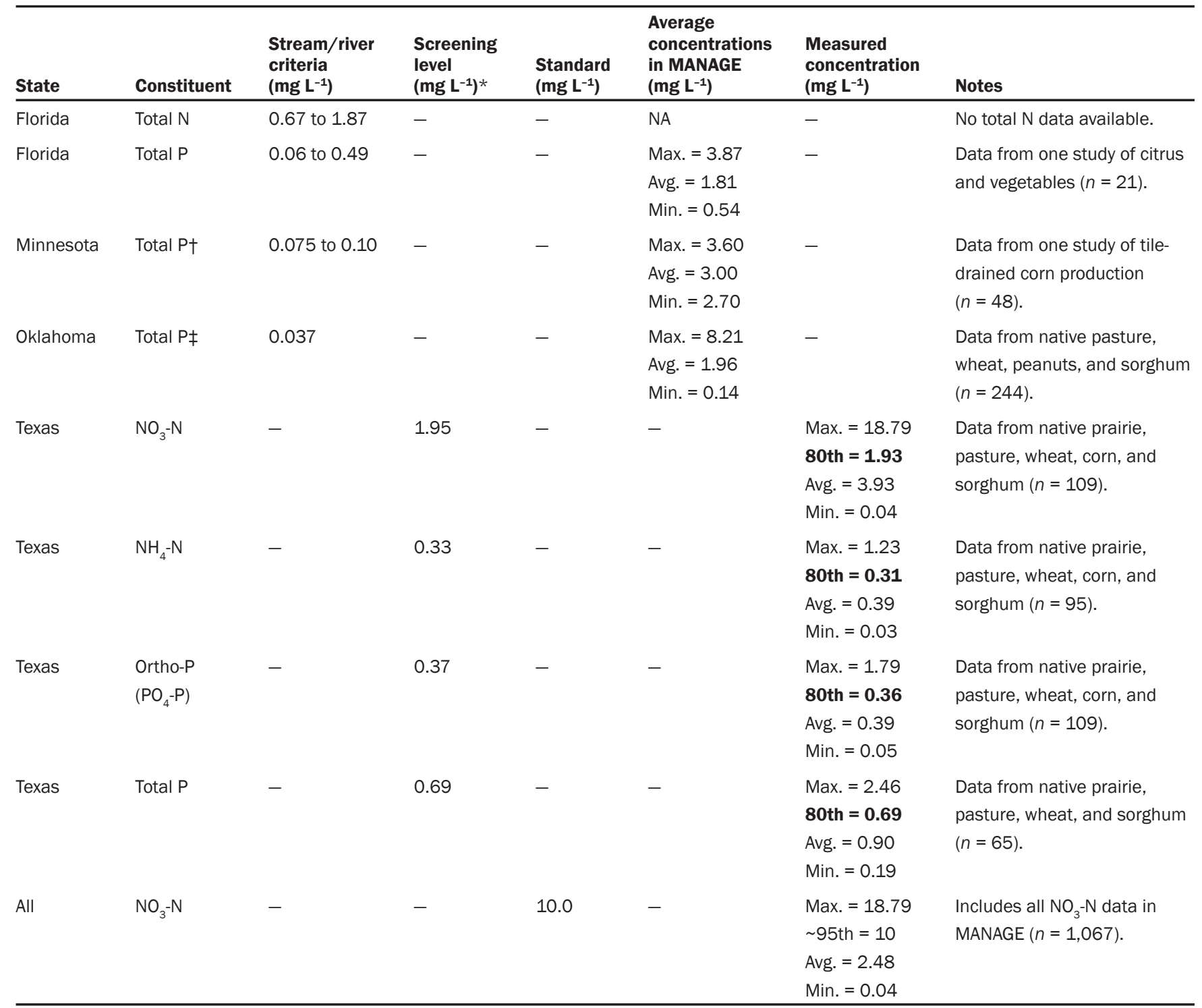

Note: MANAGE $=$ Measured Annual Nutrient loads from AGricultural Environments database. $\mathrm{N}=$ nitrogen. $\mathrm{P}=$ phosphorus. $\mathrm{NO}_{3}-\mathrm{N}=$ nitrate-nitrogen. $\mathrm{NH}_{4}-\mathrm{N}=$ ammonium-nitrogen. $n=$ number of site-years.

*A "concern" for excessive nutrient levels is indicated if the screening level is exceeded in greater than $20 \%$ of samples (if the 80 th percentile shown in bold text exceeds the screening level).

†Part of an integrated water quality standard that includes diel dissolved oxygen (0) flux and biochemical 0 demand.

‡For scenic rivers.

$\mathrm{kg} \mathrm{P} \mathrm{ha}{ }^{-1}$ ) based on predicted annual losses (Osmond et al. 2006).

State $\mathrm{P}$ indices were designed to assess the risk of $\mathrm{P}$ runoff loss and to identify the soil, topographic, and management factors that influence loss and to be part of the planning process between land user and resource planner in selecting conservation practices. In fact, USDA NRCS cautions that "the P Index is not intended to be an evaluation scale for determining whether land users are abiding within water quality or nutrient management standards that have been established by local, state, or federal agencies. Any attempt to use this index as a regulatory scale would be grossly beyond the intent of the assessment tool and the concept and philosophy of the working group that developed it" (USDA NRCS 2012).

Recommendations. With this precaution understood and appreciated, a P index or environmental index approach could be utilized to indirectly assess nutrient runoff. Such an approach based on a widely accepted procedure specific to each state (although not vigorously validated in all regions) could facilitate relatively inexpensive assessment while providing producers significant freedom to design conservation measures (BMPs and management strategies). However, lack of expected reductions in $\mathrm{P}$ impaired surface waters and in soil test $\mathrm{P}$ levels has brought into question the value 


\section{Table 4}

Texas Commission on Environmental Quality nutrient screening levels for nutrient parameters in Texas freshwater streams and nutrient concentrations measured (8oth percentile) from various field-scale watersheds at the USDA Agricultural Resource Service Riesel Watersheds.

\begin{tabular}{|c|c|c|c|c|c|c|c|}
\hline $\begin{array}{l}\text { Nutrient } \\
\text { parameter }\end{array}$ & $\begin{array}{l}\text { Screening } \\
\text { level } \\
\left(\mathrm{mg} \mathrm{L}^{-1}\right)\end{array}$ & $\begin{array}{l}\text { Reference } \\
\text { remnant } \\
\text { prairie SW12 }\end{array}$ & $\begin{array}{l}\text { Pasture with } \\
\text { recommended } \\
\text { litter rate } \\
\text { W10 }\end{array}$ & $\begin{array}{l}\text { Pasture with } \\
\text { excessive } \\
\text { nutrients } \\
\text { Y14 }\end{array}$ & $\begin{array}{l}\text { Cropland with } \\
\text { excessive } \\
\text { inorganic } N \\
\text { Y6 }\left(\mathrm{mg} \mathrm{L}^{-1}\right)\end{array}$ & $\begin{array}{l}\text { Cropland with } \\
\text { recommended } \\
\text { litter and } \\
\text { inorganic } \\
\text { N Y13 }\end{array}$ & $\begin{array}{l}\text { Cropland with } \\
\text { excessive } \\
\text { nutrients Y8 }\end{array}$ \\
\hline $\mathrm{NO}_{3}-\mathrm{N}$ & 1.95 & 0.16 & 0.37 & 0.25 & 1.31 & 5.18 & 7.65 \\
\hline $\mathrm{NH}_{4}-\mathrm{N}$ & 0.33 & 0.12 & 0.10 & 0.15 & 0.19 & 0.37 & 0.34 \\
\hline Total P & 0.69 & - & - & - & - & - & - \\
\hline $\begin{array}{l}\text { Runoff } \\
\text { events }(n)\end{array}$ & - & 88 & 36 & 29 & 17 & 29 & 24 \\
\hline $\begin{array}{l}\text { Time } \\
\text { period }\end{array}$ & - & 2000 to 2012 & 2000 to 2007 & 2000 to 2007 & 2008 to 2012 & 2008 to 2012 & 2008 to 2012 \\
\hline
\end{tabular}

of these indices for protecting water quality (Sharpley et al. 2012). Next generation P indices will require more rigorous evaluation to determine if they are accurately predicting off-site P losses.

Field-Scale Model (Indirect Assessment). In recent years, enhanced hydrologic and nutrient cycling routines have been incorporated into field-scale water quality models (e.g., Annual P Loss Estimator [APLE],Vadas et al. 2009; Environmental Policy Integrated Climate [EPIC], Wang et al. 2012) to more accurately predict nutrient loss (Vadas and White 2010). Additionally, other modeling tools have been developed to rely on proven model platforms while dramatically simplifying data inputs and usability (e.g., Pasture Phosphorus Management tool [PPM Plus], White et al. 2011; Texas BMP Evaluation Tool [TBET], White et al. 2012). For example, PPM Plus is used in Oklahoma to predict the effectiveness of publicly funded conservation practices in selected priority watersheds. Similarly, the Texas State Soil and Water Conservation Board (TSSWCB) uses TBET to estimate nutrient losses with and without practices outlined in their Water Quality and Nutrient Management Plans and report that information to the Texas State Legislature.

Recommendations. These applications illustrate the usefulness of field-scale modeling tools to estimate edge-of-field nutrient loss. They incorporate state-of-the-art science while being designed for use by planners and managers without extensive modeling expertise. In addition, some of these tools predict edge-of-field runoff and sediment transport in addition to $\mathrm{N}$ and $\mathrm{P}$ loss. These models are not as widely accepted as P indices, and like $\mathrm{P}$ indices they have not been vigorously validated in all regions. However, they can facilitate relatively inexpensive, scientific assessment of $\mathrm{N}$ and $\mathrm{P}$ runoff while providing producers significant freedom to design conservation measures (BMPs and management strategies). In addition, they provide loss estimates that can be used directly with larger scale models to assess downstream water quality impacts, which is an important benefit.

Certainty Programs (Indirect Assessment). Several states currently have or are developing agricultural certainty programs. In these programs, producers implement recommended conservation practices and maintain them for a specified amount of time, and in turn receive legal and/or financial "certainty" in essence that they are protecting water quality (Craig and Roberts 2015; Parker 2015). This alternative is supported by USEPA and USDA NRCS (State of Minnesota et al. 2012). Thus, agricultural certainty programs could also be used as indirect assessments of nutrient runoff. For example, in nonlisted watersheds in Florida, producers who enroll and properly implement prescribed BMPs are presumed to be in compliance with state water quality requirements and are insulated from local regulation under the Right to Farm Act (Craig and Roberts 2015). In Texas, operations with an approved Water Quality Management Plan and required practices installed and maintained are pre- sumed to be in compliance with state water quality laws (TCEQ and TSSWCB 2012).

This alternative presents producers with significant freedom to implement BMPs and other management strategies and provides them with considerable legal protection if they comply with program certification requirements. Certainty programs rely on science-based selection and appropriate implementation of BMPs to protect water quality. In addition, committed cooperation between producer and state/federal agencies is required to provide assurance that practices and approved management strategies are maintained. Additionally, renewal requirements are critical so that technological advances and improved knowledge are implemented periodically. To increase the likelihood for downstream water quality protection, certainty programs should target the broader agricultural community instead of limited segments and should prioritize high risk areas.

Recommendations. Based on the present evaluation, certainty programs offer the most promise for achieving acceptable nutrient runoff levels from agricultural fields. Such programs build on previous successes of voluntary conservation practices, have support from USEPA and USDA, utilize the best available science to select effective conservation practices, and they do not face many of the challenges inherent in the other direct comparison and indirect assessment alternatives.

The agricultural community (including producers, researchers, technical support 


\section{Figure 4}

Nutrient concentrations ( $\left.\mathrm{mg} \mathrm{L}^{-1}\right)$ reported in the Measured Annual Nutrient loads from AGricultural Environments database for corn ( 36 sites, 176 site-years), cotton (10 sites, 33 site-years), wheat (13 sites, 73 site-years), soybean (17 sites, 137 site-years), and pasture ( 90 sites, 498 site-years).
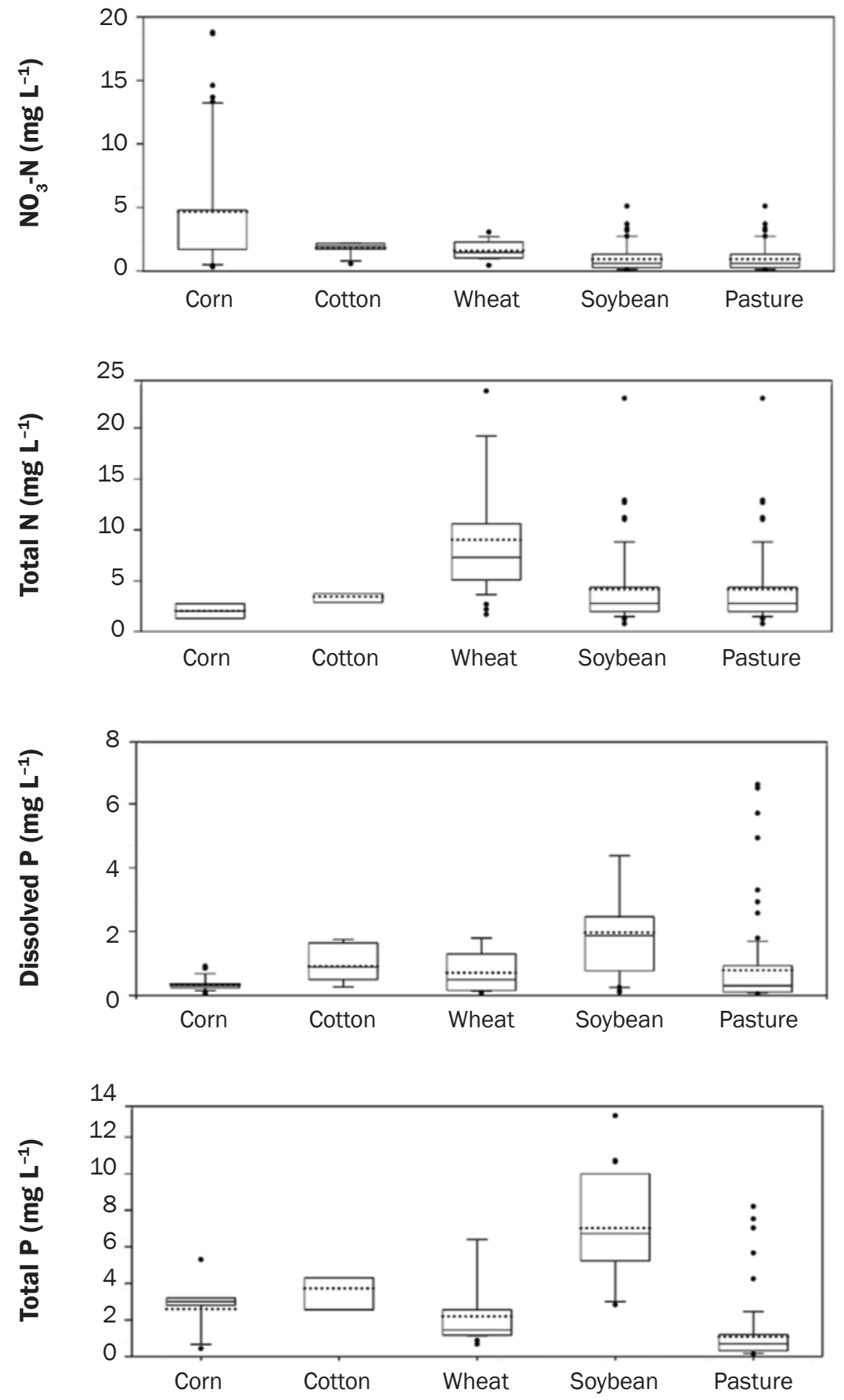

providers, extension agents, educators, and industry) has developed and implemented effective management techniques and conservation practices, and resulting improvements in water quality are well-documented. However, in regions with water quality problems due to accelerated nutrient enrichment to which agriculture is a significant contributor, it is critical that certainty programs contain mechanisms to determine whether or not (1) management recommendations (including fertilizer recommendations, yield goals, and other in-field and edge-of-field practices) are based on currently accepted science, and (2) an appropriate number of producers are participating in the program. If management recommendations are ineffective, outdated, or underutilized, then research, extension/education, and industry personnel across all agricultural sectors should commit to developing and transferring enhanced understanding and improved practices to agricultural producers (for nutrients this includes soil testing for plant available nutrients as well as appropriate nutrient timing, rate, type, and method recommendations). Similarly, producers will need to utilize effective management techniques and conservation practices. If not, the agricultural community (including researchers, extension/educators, industry, and producers) that supports/implements poor management decisions and thus shares in the blame should not be surprised by increased regulatory pressure.

Relation to Downstream Water Quality and Nutrient Criteria. In the present discussion, the relation between edge-of-field nutrient runoff and downstream water quality has been avoided to focus solely on alternatives for assessing nutrient runoff at the edge-of-field. It was important to focus this manuscript on the field scale where producers make land management decisions because the water resource community has not yet adequately addressed the critical question: What are acceptable levels of nutrients in runoff from agricultural fields? However, it is also critical to begin a discussion of the relation of edge-of-field nutrient runoff to downstream water quality and nutrient criteria.

One important benefit of establishing nutrient runoff targets for agriculture is linking these water quality goals with modeling tools and other decision aids to support planning and management at the field- and watershed scale. Ideally, scientists 


\section{Figure 5}

Nutrient load $\left(\mathrm{kg} \mathrm{ha}^{-1}\right)$ reported in the Measured Annual Nutrient loads from AGricultural Environments database for corn (70 sites, 370 site-years), cotton (11 sites, 121 site-years), wheat (22 sites, 153 site-years), soybean (26 sites, 167 site-years), and pasture (123 sites, 826 site-years).
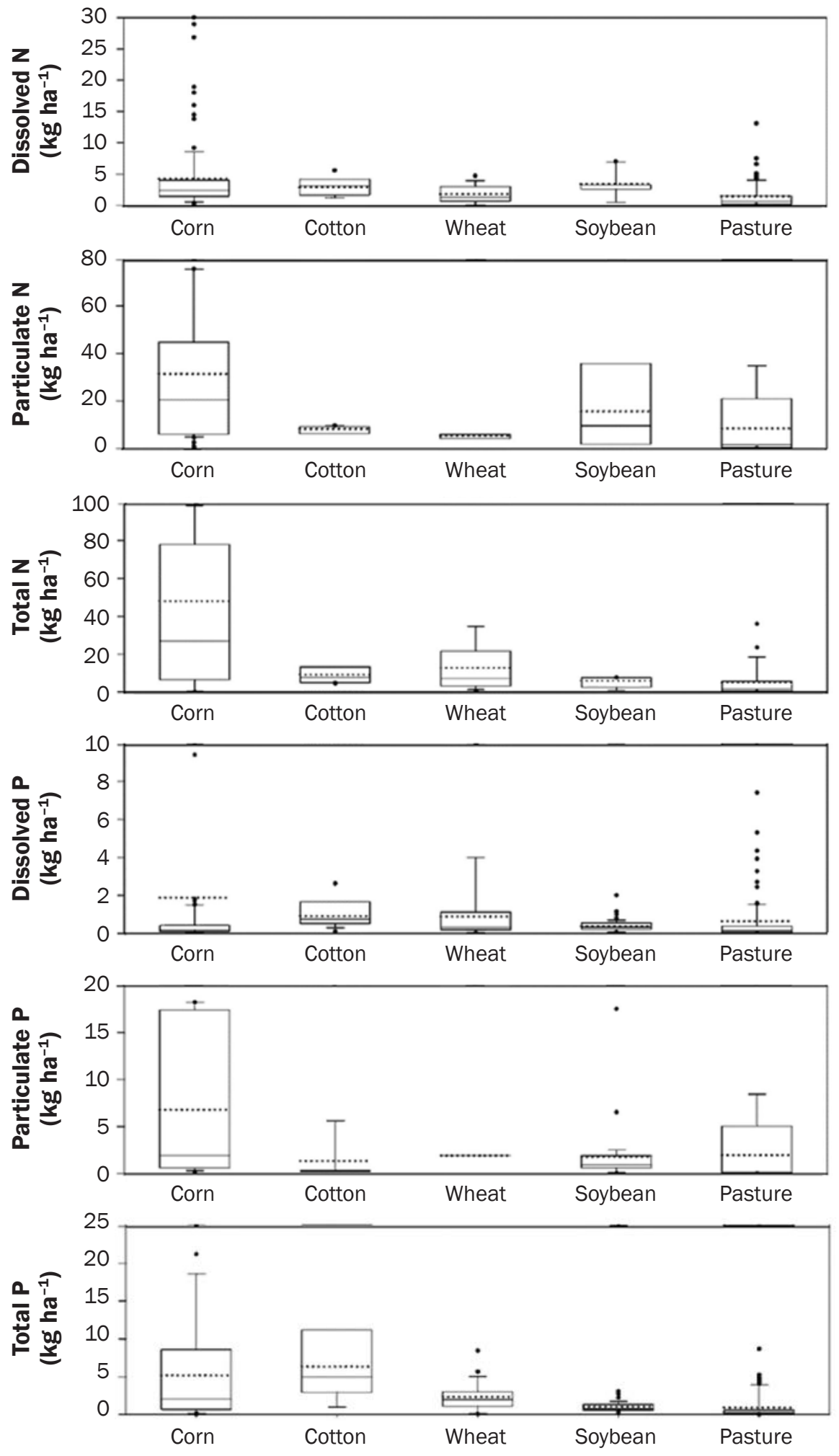

and stakeholders can establish a reasonable TMDL allocation for impaired waters and work together to determine reductions in upstream sources (e.g., agriculture and WWTPs) to achieve the desired water quality goal. These tools arguably represent the only valid scientific approach for determining whether nutrient losses are acceptable (in terms of meeting some edge-of-field target) and for assessing the contribution of numerous sources to estimate whether downstream nutrient criteria will be met. This linkage is critical because of the complexity of NPS processes as summarized subsequently:

- Biological responses (i.e., excessive algal growth and accelerated eutrophication) across natural and agricultural systems are complex and exhibit substantial spatial and temporal variability due to rainfall, topography, climate, nutrient fate and transport mechanisms, and ecosystem characteristics. These factors make it difficult to determine cause and effect relationships to derive appropriate numeric criteria (Barnett and O’Hagan 1997).

- Runoff and nutrient fate and transport (including other pathways, e.g., deep leaching and artificial drainage) depends on site-specific factors such as climate, soils, topography, and previous land use/ management (Novotny and Olem 1994; Sharpley et al.1996); thus, management on different fields will have differing effects on downstream water quality. Similarly, practices that reduce runoff and leaching of soluble $\mathrm{N}$ and $\mathrm{P}$ can increase the transport of particulate forms. The contribution of very large, infrequent storms (e.g., 25-year, $24 \mathrm{hr}$ ), which is commonly exempt from CAFO and WWTP regulations because it is difficult to manage and address, adds additional complexity.

- Considerable lag time can occur between implementation of BMPs and detection of water quality changes depending on several factors (e.g., transport rate and path, pollutant sorption properties, and ecosystem linkages; Meals et al. 2010) and can range from years to decades for excessive $\mathrm{P}$ levels in agricultural soils. For example, soils with high soil test $\mathrm{P}$ may take more than 14 years to return to optimum agronomic P levels even with no further $\mathrm{P}$ application (McCollum 1991; Kleinman et al. 2011; Svanbäck et al. 2015); therefore, they remain a source transferring P to surface waters over long 
periods of time, reducing the immediate impacts of $\mathrm{P}$ loss reduction strategies (Maguire et al. 2009).

\section{Summary and Conclusions}

The present work analyzed various alternatives for assessing edge-of-field nutrient runoff. Based on these analyses, direct comparisons can definitively determine whether or not runoff water quality at the edge-offield exceeds target levels; however, they suffer from many scientific and practical challenges. First and foremost, direct comparisons require measurement of water quality, which would be prohibitively difficult and expensive, especially considering the large number of farms and the substantial temporal and spatial variability in nutrient runoff. However, in local areas with high profile/high value water bodies, this might be a feasible option. In addition, determining local/regional targets that are achievable with best available technology and that differentiate between recommended management and poor management is a daunting task. Even using data compilations to establish acceptable nutrient runoff would be difficult because of the limited amount of published land use specific data and the unequal distribution between land uses, regions, etc. In addition, evaluation of possible exceedances in edge-of-field targets would be directly affected by sample type (e.g., discrete versus composite, time versus flow based, or random grab) and data reporting options (individual sample, EMC, annual mean, load versus concentration, etc.).

Similarly, soil test P or P index (or similar "environmental index") indirect assessment alternatives provide a relative ranking of nutrient loss potential, can help target effort and resources on fields with the greatest likelihood of excess nutrient runoff, and allow substantial freedom to design methods to achieve water quality goals. However, they are also unable to differentiate the numerous natural and controllable factors that affect $\mathrm{N}$ and $\mathrm{P}$ runoff magnitudes and timing. Also, none of the indirect assessment methods are able to definitively confirm acceptable water quality. Whether "direct comparisons" or "indirect assessments" are used, some type of monitoring (e.g., measured water quality data or practice implementation and maintenance data) will be required to provide some assurance of water quality protection (Barnett and O'Hagan 1997).
Based on the present evaluation, certainty programs offer the promise for achieving acceptable nutrient runoff levels from agricultural fields. Certainty programs have support from USEPA and USDA; they do not face many of the challenges inherent in the other direct comparison and indirect assessment alternatives; they allow substantial freedom to design methods to achieve water quality goals; they provide legal protection to producers; and they utilize the best available science to assure protection of water quality, although they do not provide direct confirmation. This is in essence a "best available technology" approach such as used in many National Pollutant Discharge Elimination System programs to protect water quality but not require dischargers to meet baseline water quality. In conjunction with certainty programs, field-scale models linked with watershed decision support tools can estimate the impact of on-farm management, assess the contribution of numerous sources including agriculture, and provide science-based predictions of the impact on downstream water quality.

Most would agree that agriculture should, to the extent possible, minimize its contribution to water quality degradation and should be allowed to use a variety of cost-effective conservation production practices to protect water quality and achieve both short- and long-term profitability. The state of Florida (FDACS 2017) provides a good description of how this process should work: (1) BMPs should be cost-effective with practicable actions for improving water quality and/or water conservation while maintaining or enhancing agricultural production; (2) that BMPs be science-based, developed through research, field tested, and reviewed by experts; (3) that structural and nonstructural/management BMPs be utilized where appropriate; and (4) that the focus of BMPs is managing inputs to provide for economic environmental, and agronomic efficiency in production agriculture. Expecting agricultural producers to use cost-prohibitive (unprofitable) practices to protect water quality is unrealistic, as are unsubstantiated claims that nutrient BMPs are cost prohibitive. Similarly, downstream interests and water users (agriculture, environmental groups, recreational enthusiasts, cities, and industries) who rightly expect clean water from upstream should also appreciate that nutrient runoff from even native prairies and virgin forests contains nutrients and thus is not pure.

Recognizing that numerous sources contribute nutrients to surface waters, multisector approaches are likely necessary in high profile cases of excess nutrients (Smith et al. 2015). One such approach was implemented by the State of Ohio Legislature in response to the 2014 harmful algal bloom in Lake Erie. The 2015 Ohio Senate Bill 1 prohibited spreading of manure and fertilizer on frozen ground and saturated soil in the Western Lake Erie Basin, required WWTPs to begin monthly monitoring of dissolved $\mathrm{P}$, and beginning in 2020 will ban dumping of dredged material into the lake (Borchardt 2015; Londo et al. 2015)

For all of these reasons, it was important to present scientific realities and practical challenges related to assessing nutrient runoff. We encourage the application of a scientific basis and consideration and involvement of all $\mathrm{N}$ and $\mathrm{P}$ sources (e.g., agricultural and urban fertilization, WWTPs, septic systems, wildlife, mineral weathering, and streambank erosion) working together to mitigate water quality degradation from excess nutrients.

\section{Acknowledgements}

Kori Higgs (graduate student, North Carolina A\&T, Greensboro, North Carolina) was instrumental in developing the original organization of this manuscript, and Kati Migliaccio (professor, University of Florida, Gainesville, Florida) provided extensive review and valuable comments.

\section{Disclaimer}

USDA is an equal opportunity employer and provider.

\section{References}

Ahuja, L.R., A.N. Sharpley, M. Yamamoto, and R.G. Menzel. 1981. The depth of rainfall-runoff-soil interaction as determined by ${ }^{32} \mathrm{P}$. Water Resources Research 17:969-974.

American Farmland Trust. 2013. Controlling Nutrient Runoff on Farms. DeKalb, IL: American Farmland Trust, Center for Agriculture in the Environment.

Barnett, V., and A. O'Hagan. 1997. Setting Environmental Standards: The Statistical Approach to Handling Uncertainty and Variation, 1st edition. London, UK: Chapman \& Hall.

Borchardt, J. 2015. Bill targeting Lake Erie algal blooms passes Ohio Senate. Columbus, OH: Northeast Ohio Media Group. http://www.cleveland.com/open/ index.ssf/2015/02/bill_targeting_lake_erie_algal_ blooms_passes_ohio_senate.html.

Chimney, M.J., and G. Goforth. 2001. Environmental impacts to the Everglades ecosystem: A historical perspective and restoration strategies. Water Science and Technology 44:93-100. 
Craig, R.K., and A.M. Roberts. 2015. When will governments regulate nonpoint source pollution? A comparative perspective. Boston College Environmental Affairs Law Review 42(1). http://lawdigitalcommons. bc.edu/ealr/vol42/iss1/2/.

DeLaune, P.B., P.A. Moore, D.K. Carman, A.N. Sharpley, B.E. Haggard, and T.C. Daniel. 2004. Development of a phosphorus index for pastures fertilized with poultry litter: Factors affecting phosphorus runoff. Journal of Environmental Quality 33(6):2183-2191.

Dodds, W., and E. Welch. 2000. Establishing nutrient criteria in streams. Journal of North American Benthological Society 19(1):186-196.

Environmental Law Institute. 1998. Almanac of Enforceable State Laws to Control Nonpoint Source Water Pollution.

Evans-White, M., B. Haggard, and J. Scott. 2013. A review of stream nutrient criteria development in the United States. Journal of Environmental Biology 42:1002-1014.

Grandt, S., Q.M. Ketterings, A.J. Lembo, and F. Vermeylen. 2008. In-field variability of soil test phosphorus and implications for agronomic and environmental phosphorus management. Soil Science Society of America Journal 74:1800-1807.

FDACS. 2017. BMPs at a Glance. www.freshfromflorida. com/Divisions-Offices/Agricultural-Water-Policy/ Enroll-in-BMPs/BMPs-at-a-Glance.

FDEP (Florida Department of Environmental Protection). 2012. Nutrient Criteria Technical Support Document: Development of Numeric Criteria for Florida Lakes, Spring Vents and Streams. Standards and Assessment Section. www.dep.state.fl.us/water/wqssp/nutrients/ docs/tsd-nnc-lakes-springs-streams.pdf.

Florida Administrative Code, 62-302.530. Florida Department of Environmental Protection. Surface Water Quality Standards.

Harmel, R.D., R.L. Haney, D.R. Smith, M. White, and K.W. King. 2014. USDA-ARS Riesel Watersheds, Riesel, Texas, USA: Water quality research database. Water Resources Research 50(10):8374-8382.

Harmel, R.D., S. Potter, P. Casebolt, K. Reckhow, C.H. Green, and R.L. Haney. 2006. Compilation of measured nutrient load data for agricultural land uses in the United States. Journal of American Water Resources Association 42:1163-1178.

Harmel, D., S. Qian, K. Reckhow, and P. Casebolt. 2008. The MANAGE database: Nutrient load and site characteristic updates and runoff concentration data. Journal of Environmental Quality 37(6):2403-2406.

Harmel, R.D., D.R. Smith, R.L. Haney, and M. Dozier. 2009. Nitrogen and phosphorus runoff from cropland and pasture fields fertilized with poultry litter. Journal of Soil and Water Conservation 64(6):400-412, doi:10.2489/jswc.64.6.400.

Haskell, J. 2007. Agricultural nonpoint source pollution and eutrophication: A survey of environmental responsibility in the federal system and case study of the Chautauqua Lake Watershed, New York State. Vanderbilt Undergraduate Research Journal 3(1):1-19.

Henderson, O. 2015.Vilsack urging collaboration rather than confrontation over water quality issues. www.radioiowa. com/2015/10/15/vilsack-urging-collaboration-ratherthan-confrontation-over-water-quality-issues/.

Johnson, A.M., D.L. Osmond, and S.C. Hodges. 2005. Predicted impact and evaluation of North Carolina's phosphorus indexing tool. Journal of Environmental Quality 34:1801-1810.

Kleinman, P.J.A., A.N. Sharpley, A.R. Buda, R.W. McDowell, and A.L. Allen. 2011. Soil controls of phosphorus in runoff: Management barriers and opportunities. Canadian Journal of Soil Science 91:329-338.

Lemunyon, J.L., and R.G. Gilbert. 1993. The concept and need for a phosphorus assessment tool. Journal of Production Agriculture 6:483-486.

Londo, A.J., G. LaBarge, H. Watters, S. Culman, M.A. Rose, P. Hall, G. Arnold, S. Custer, E. Richer, S. Noggle, and C. Penrose. 2015. Water quality and nutrient management extension programs in Ohio. Journal of Contemporary Water Research and Education 156:48-55.

Maguire, R.O., G.H. Rubaek, B.E. Haggard, and B.H. Foy. 2009. Critical evaluation of the implementation of mitigation options for phosphorus from field to catchment scales. Journal of Environmental Quality 38:1989-1997.

Mallarino, A.P., B.M. Stewart, J.L. Baker, J.D. Downing, and J.E. Sawyer. 2002. Phosphorus indexing for cropland: Overview and basic concepts of the Iowa phosphorus index. Journal of Soil and Water Conservation 57(6):440-447.

McCollum, R.E. 1991. Buildup and decline in soil phosphorus: 30-year trends on a Typic Umprabuult. Agronomy Journal 83:77-85.

McFarland, A.M., and L.M. Hauck. 1999. Relating agricultural land uses to in-stream stormwater quality. Journal of Environmental Quality 28(3):846-844.

Meals, D.W., S.A. Dressing, and T.E. Davenport. 2010. Lag time in water quality response to best management practices: A review. Journal of Environmental Quality 39:85-96.

Mueller, D.K., and D.R. Helsel. 1996. Nutrients in the Nation's water: Too much of a good thing? US Geological Survey Circular 1136. Washington, DC: US Geological Survey.

Mzuku, M., R. Khosla, R. Reich, D. Inman, F. Smith, and L. MacDonald. 2005. Spatial variability of measured soil properties across site-specific management zones. Soil Science Society of America Journal 69:1572-1579.

National Academy of Sciences. 2012. Review of the EPA's Economic Analysis of Final Water Quality Standards for Lakes and Flowing Waters in Florida: Committee to Review EPA's Economic Analysis of Final Water Quality Standards for Nutrients for Lakes and Flowing Waters in Florida. Washington, DC: National Academy of Sciences, Water Science and Technology Board, Division on Earth and Life Studies.

Novotny, V., and H. Olem. 1994. Water Quality: Prevention, Identification, and Management of Diffuse Pollution. New York:Van Nostrand Reinhold.

NWQMC (National Water Quality Monitoring Council). 2012. Establishing a Collaborative and Multipurpose National Network of Reference Watershed and Monitoring Sites for Freshwater Streams in the United States. Washington, DC: US Geological Survey.

Omernik, J.M. 1987. Ecoregions of the conterminous United States. Map (scale 1:7,500,000). Annals of the American Association of Geographers 77:118-125.

Oregon Administrative Rule 603-090-0000. Oregon Department of Agriculture Division 90, Agricultural Water Quality Management Program.
Osmond, D., M. Cabrera, S. Feagley, G. Hardee, C. Mitchell, P. Moore, R. Mylavarapu, J. Oldham, J. Stevens, W.Thom, F.Walker, and H. Zhang. 2006. Comparing ratings of the southern phosphorus indices. Journal of Soil and Water Conservation 61(6):325-337.

Parker, L.D. 2015. Agricultural Certainty in Oklahoma: A Survey of Agricultural Producers and Potential Phosphorus Load Reductions within the Illinois River Watershed. Master's thesis, Oklahoma State University, Stillwater, OK.

Poole, G.C., J.B. Dunham, D.M. Keenan, S.T. Sauter, D.A. McCullough, C. Mebane, J.C. Lockwood, D.A. Essig, M.P. Hicks, D.J. Sturdevant, E.J. Materna, S.A. Spalding, J. Risley, and M. Deppman. 2004. The case for regime-based water quality standards. BioScience Roundtable 54(2):155-161.

Regan, J.T., O. Fenton, K. Daly, J. Grant, D.P. Wall, and M.G. Healy. 2014. Effects of overland flow on critical soil test phosphorus thresholds in tillage soils. Water, Air, and Soil Pollution 225:2044.

Schroeder, P.D., D.E. Radcliffe, M.L. Cabrera, and C.D. Belew. 2004. Relationship between soil test phosphorus and phosphorus in runoff: Effects of soil series variability. Journal of Environmental Quality 33:1452-1463.

Scott, J.T., B.E. Haggard, A.N. Sharpley, and J.J. Romeis. 2011. Change point analysis of phosphorus trends in the Illinois River (Oklahoma) demonstrates the effects of watershed management. Journal of Environmental Quality 40(4):1249-56.

Sharpley, A.N., D. Beegle, C. Bolster, L. Good, B. Joern, Q. Ketterings, J. Lory, R. Mikkelsen, D. Osmond, and P. Vadas. 2012. Phosphorus indices: Why we need to take stock of how we are doing. Journal of Environmental Quality 41:1711-1719.

Sharpley, A.N., T.C. Daniel, J.T. Sims, and D.H. Pote. 1996. Determining environmentally sound soil phosphorus levels. Journal of Soil and Water Conservation 51(2):160-166.

Sharpley, A.N., R.W. McDowell, J.L. Weld, and P.J.A. Kleinman. 2001. Assessing site vulnerability to phosphorus loss in an agricultural watershed. Journal of Environmental Quality 30:2026-2036.

Sharpley, A.N., J.L. Weld, D. Beegle, P.J.A. Kleinman, W.J. Gburek, P.A. Moore, and G. Mullins. 2003. Development of phosphorus indices for nutrient management planning strategies in the United States. Journal of Soil and Water Conservation 58(3):137-152.

Smith, R.A., R.B. Alexander, and G.E. Schwarz. 2003. Natural background concentrations of nutrients in streams and rivers of the conterminous United States. Environmental Science and Technology 37(14):3039-3047.

Smith, D.R., K.W. King, and M.R. Williams. 2015. What is causing the harmful algal blooms in Lake Erie? Journal of Soil and Water Conservation 70(2):27A-29A, doi: $10.2489 /$ jswc.70.2.27A.

State of Minnesota, USDA, and USEPA (US Environmental Protection Agency). 2012. Memorandum of Understanding: Engaging in a State and Federal Partnership in Support of the Minnesota Agricultural Water Quality Certification Program.

Stoddard, J.L., D.P. Larsen, C.P. Hawkins, R.K. Johnson, and R.H. Norris. 2006. Setting expectations for the ecological condition of streams: The concept of reference condition. Ecological Applications 16(4):1267-1276. 
Svanbäck, A., B. Ulén, L. Bergström, and P.J.A. Kleinman. 2015. Long-term trends in phosphorus leaching and changes in soil phosphorus with phytomining. Journal of Soil and Water Conservation 70(2):121-132, doi:10.2489/jswc.70.2.121.

Tarkalson, D.D., and R.L. Mikkelsen. 2004. Runoff phosphorus losses as related to soil phosphorus and degree of phosphorus saturation on Piedmont soils under conventional and no-tillage. Communications in Soil Science and Plant Analysis 35:2987-3007.

TCEQ (Texas Commission on Environmental Quality). 2010. 2010 Guidance for Assessing and Reporting Surface Water Quality in Texas. Austin, TX: Surface Water Quality Monitoring Program, Monitoring and Assessment Section, Water Quality Planning Division.

TCEQ and TSSWCB (Texas State Soil and Water Conservation Board). 2012. Texas Nonpoint Source Management Programs. SFR-068/12. Austin, TX Texas Commission on Environmental Quality, Texas State Soil and Water Conservation Board.

Turner, B.L., M.A. Kay, and D.T. Westermann. 2004 Phosphorus in surface runoff from calcareous arable soils of the semiarid western United States. Journal of Environmental Quality 33:1814-1821.

USDA ERS (Economic Research Service). 1999. Economics of Water Quality Protection from Nonpoint Sources: Theory and Practice. Resource Economics Division, Agricultural Economic Report Number 782.

USDA NASS (National Agricultural Statistics Service). 2014. Agricultural Statistics 2014. Washington, DC: USDA National Agricultural Statistics Service.

USDA NRCS (Natural Resources Conservation Service). 2011.Assessment of the Effects of Conservation Practices on Cultivated Cropland in the Ohio-Tennessee River Basin, Conservation Effects Assessment Project (CEAP), November 2011. Washington, DC: USDA Natural Resources Conservation Service.

USDA NRCS. 2012. Agronomy Technical Note Number 15, Phosphorus Assessment Tool for Texas. Washington, DC: USDA Natural Resources Conservation Service.

USEPA (US Environmental Protection Agency). 1997. Nonpoint Source: Draft Proposed National Strategy for Strengthening Nonpoint Source Management. Washington, DC: US Environmental Protection Agency. http://water.epa.gov/polwaste/nps/archives/index. cfm\#2.

USEPA. 2001. Ambient Water Quality Criteria Recommendations Information Supporting the Development of State and Tribal Nutrient Criteria: Rivers and Streams in Nutrient Ecoregion V, EPA822-B-01-014. Washington, DC: US Environmental Protection Agency, Office of Water.

USEPA. 2009. National Primary Drinking Water Regulations. EPA 816-F-09-0004. Washington, DC: US Environmental Protection Agency.

USEPA. 2015a. State Development of Numeric Criteria for Nitrogen and Phosphorus Pollution. Washington, DC: US Environmental Protection Agency. http://cfpub.epa. gov/wqsits/nnc-development/.

USEPA. 2015b. Nonpoint Source Pollution: The Nation's Largest Water Quality Problem. Washington, DC: US Environmental Protection Agency. http://water.epa. gov/polwaste/nps/outreach/point1.cfm.

USEPA. 2015c. National Summary of Impaired Waters and TMDL Information. Washington, DC: US
Environmental Protection Agency. http://iaspub.epa. gov/waters10/attains_nation_cy.control?p_report_ type $=\mathrm{T} \#$ causes_303d.

Vadas, P.A., L.W. Good, P.A. Moore, Jr., and N. Widman. 2009. Estimating phosphorus loss in runoff from manure and fertilizer for a phosphorus loss quantification tool. Journal of Environmental Quality 38:1645-1653.

Vadas, P.A., and M.J. White. 2010. Validating soil phosphorus routines in the SWAT model. Transactions of the American Society of Agricultural and Biological Engineers 53(5):1469-1476.

Wang, X., J.R. Williams, P.W. Gassman, C. Baffaut, R.C. Izaurralde, J. Jeong, and J.R. Kiniry. 2012. EPIC and APEX: Model use, calibration, and validation. Transactions of the American Society of Agricultural and Biological Engineers 55(4):1447-1462.

White, M.W., R.D. Harmel, and R.L. Haney. 2012 Development and validation of the Texas Best Management Practice Evaluation Tool (TBET) Journal of Soil and Water Conservation 67(6):525-535, doi:10.2489/jswc.67.6.525.

White, M.J., C. Santhi, N. Kannan, J.G. Arnold, R.D. Harmel, L. Norfleet, P. Allen, M. Diluzio, X. Wang, J. Attwood, E. Haney, and M. Johnson. 2014. Nutrient delivery from the Mississippi River to the Gulf of Mexico and the effects of cropland conservation. Journal of Soil and Water Conservation 69(1):26-40, doi:10.2489/jswc.69.1.26

White, M.J., D.E. Storm, M.D. Smolen, P.R. Busteed, H. Zhang, and G.A. Fox. 2011. Validation of a quantitative phosphorus loss assessment tool. Journal of Environmental Quality 43(1):224-234.

Williams, D.R. 2002. When voluntary, incentivebased controls fail: Structuring a regulatory response to agricultural nonpoint source water pollution. Washington University Journal of Law Policy 9:21-122.

Zaring, D. 1996. Agriculture, nonpoint source pollution, and regulatory control: The Clean Water Act's bleak present and future. Harvard Environmental Law Review 21:515-545.

Zheng, Z.M., T.Q. Zhang, G. Wen, C. Kessel, C.S. Tan, I.P. O'Halloran, D.K. Reid, D. Nemeth, and D. Speranzini. 2014. Soil testing to predict dissolved reactive phosphorus loss in surface runoff from organic soils. Soil Science Society of America Journal 78:1786-1796. 